\title{
In vitro evaluation of the role of antibodies against Helicobacter pylori in inhibiting adherence of the organism to gastric cells
}

\author{
M Clyne, J Thomas, L Weaver, B Drumm
}

Department of Paediatrics, University College Dublin Dublin, Ireland M Clyne B Drumm

MRC Dunn Nutrition Centre, Milton Road, Cambridge CB4 1XJ J Thomas

L Weaver

The Children's Research Centre, Our Lady's Hospital for Sick Children, Crumlin, Dublin 12, Ireland

M Clyne

B Drumm

Correspondence to:

Marguerite Clyne,

Department of Paediatrics, University College Dublin, The Children's Research Centre, Our Lady's Hospita for Sick Children, Crumlin, Dublin 12, Ireland.

Accepted for publication 23 December 1996

\begin{abstract}
Background-Once Helicobacter pylori infection is established, it is difficult to eradicate despite a persistent systemic and local immune response. It is not known whether immunisation can be used to prevent $H$ pylori infection in humans.
\end{abstract} Aims-To evaluate the effect of the human immune response on adherence of $H$ pylori to gastric cells.

Methods-Human milk from a woman infected with $H$ pylori and milk from a non-infected woman were each fractionated by chromatography on DEAE cellulose. Bacteria were incubated with either serum, human milk, human milk fractions, or secretory IgA before incubation with Kato III cells (cells from a gastric adenocarcinoma cell line). Bacterial adherence to the cells was assessed using flow cytometry.

Results-Serum from both the $H$ pylori infected and non-infected women killed $H$ pylori. This resulted from the action of complement as heating the serum to $56^{\circ} \mathrm{C}$ for 30 minutes abolished the bactericidal activity. Immunoglobulin fractions from serum of both infected and non-infected women did not inhibit $H$ pylori adherence to Kato III cells. Human milk from the woman infected with $H$ pylori and from the non-infected woman inhibited binding of $\boldsymbol{H}$ pylori to Kato III cells by 50 to $70 \%$. Secretory IgA isolated from human milk had minimal inhibitory effect on adherence and this was notably less than the inhibitory effect of whole human milk. Conclusions-Human milk inhibits adherence of $H$ pylori to Kato III cells and this inhibition is independent of whether or not the donor is infected with $H$ pylori. Secretory IgA has minimal inhibitory effect on $H$ pylori adherence.

(Gut 1997; 40: 731-738)

Keywords: Helicobacter pylori, adherence, gastric cells, secretory IgA, human milk, immunoglobulins.

Infection with Helicobacter pylori causes chronic active gastritis and duodenal ulcer disease..$^{1-5}$ It is postulated that childhood acquisition of the organism is associated with an increased risk of developing gastric cancer in later life. ${ }^{6}$ The organism colonises the antrum of the stomach and adheres to gastric mucus secreting cells. It is found in the intestine in association with areas of gastric metaplasia. ${ }^{7}$ Exactly how $H$ pylori causes disease is not known, but adherence to the gastric mucosa is thought to be an important first step in the establishment of infection. Studies have shown that secretory $\operatorname{Ig} A$ ( $\operatorname{Ig} A$ ) can interfere with the ability of some enteric pathogens to establish infection. ${ }^{8-11}$ Others have shown that sIgA can inhibit bacterial adherence. ${ }^{12} 13$ An ideal $H$ pylori vaccine should probably stimulate $H$ pylori specific sIgA antibodies in gastric secretions, which would prevent $H$ pylori infection. However, infected individuals elicit a strong specific systemic and local antibody response to the infection. ${ }^{14}{ }^{15}$ Despite this vigorous immune response, $H$ pylori is not eradicated and unless an infected individual is treated with a combination of antibiotics, lifelong chronic infection usually develops. It is not known whether immunisation can prevent $H$ pylori infection in humans. Czinn and Nedrud ${ }^{16}$ showed that repetitive oral immunisation with $H$ pylori antigens and cholera toxin induced a vigorous gastrointestinal IgA anti- $H$ pylori response in mice and ferrets. Mice can be protected from infection by $H$ felis by immunisation with sonicated extracts of $H$ felis given in combination with cholera toxin. ${ }^{17}$ Recombinant $H$ pylori urease can also protect mice from infection by $H$ felis. ${ }^{18-20}$ In addition, passive immunisation with both IgA and IgG urease specific monoclonal antibodies prevents $H$ felis infection in mice. ${ }^{21} 22$ Thomas et $a l^{23}$ reported that children in The Gambia who were breastfed by mothers that had high titres of specific anti-H pylori sIgA in their milk were protected from infection for a longer period than children whose mothers had lower anti- $H$ pylori titres. It was postulated that specific antibodies in human milk passed from mother to child during breast feeding are protective against infection by $H$ pylori. However, most children were infected by 12 months of age. Our aim was to measure the effect of (1) human serum, (2) a fraction of human serum containing immunoglobulin, (3) human milk, and (4) sIgA from $H$ pylori infected and from non-infected individuals, on adherence of the organism to gastric cells to determine whether infected individuals produce specific antibodies capable of inhibiting adherence. 


\section{Methods}

BACTERIAL STRAINS

Bacteria were isolated from antral biopsy material obtained from children undergoing upper gastrointestinal endoscopy. They were grown on Columbia blood agar (Gibco, Paisley, Scotland) plates containing 7\% (vol/ vol) defibrinated horse blood in an atmosphere of $5 \% \quad \mathrm{O}_{2}$ and $10 \% \quad \mathrm{CO}_{2}$. Bacteria were identified as $H$ pylori on the basis of colony morphology, Gram stain and the production of urease, oxidase and catalase. Strains were stored at $-70^{\circ} \mathrm{C}$ as described previously. ${ }^{24}$ For each assay, a vial of bacterial cells was thawed and cultured on blood agar plates for three days at $37^{\circ} \mathrm{C}$ under microaerobic conditions. Bacteria were harvested by rinsing the surface of each plate with $5 \mathrm{ml}$ phosphate buffered saline (PBS: Dulbecco's formula A, $\mathrm{pH} \mathrm{7 \cdot 3)}$ and removing growth by scraping with a sterile swab. Bacteria were washed once in PBS by centrifugation at $3600 \mathrm{~g}$ for 15 minutes. Quantitation of bacteria in suspension was determined by optical density measurement at $450 \mathrm{~nm}$ and by viable counts. Appropriate dilutions of the bacterial suspensions were spread on Columbia blood agar plates, and after incubation of plates at $37^{\circ} \mathrm{C}$ under microaerobic conditions for five days, colony forming units (CFU) were enumerated. The strain used for all of these studies was a clinical isolate (PU3) from the gastric biopsy specimen of a child with gastritis and peptic ulcer disease. Confirmatory studies were performed with five additional clinical isolates: PU11, PU17, PU37, PU38, and PU40.

\section{CELL CULTURE}

Kato III cells are gastric adenocarcinoma cells obtained from the American Type Culture Collection, Rockville, Maryland, USA. These were grown without antibiotics in RPMI 1640 medium (Gibco) containing $20 \mathrm{mM}$ HEPES (N-2-hydroxyethylpiperazine-N'-2-ethanesulphonic acid) buffer and $12 \mathrm{mM}$ sodium bicarbonate supplemented with $10 \%$ (vol/vol) fetal calf serum in polystyrene tissue culture flasks at $37^{\circ} \mathrm{C}$. Cells grew both in suspension phase and attached to the base of the flask. For use in adherence assays, cells were scraped from the flask using a Rubber Policeman (Costar, Cambridge, MA, USA) and centrifuged at $200 \mathrm{~g}$ for five minutes. Cells were resuspended in RPMI 1640 medium and counted by microscopy using a haemocytometer.

SERUM

Blood was collected from children who had undergone endoscopy and whose $H$ pylori status was checked by gastric biopsy culture, CLO test (Delta West Ltd, Bentley, Australia) and histology. The blood was allowed to clot and the serum removed. The serum was tested for its ability to agglutinate $H$ pylori using a standard slide agglutination technique. ${ }^{25}$ The serum was aliquoted and stored at $-20^{\circ} \mathrm{C}$ until use. Immunoglobulins were precipitated from the serum with $\left(\mathrm{NH}_{4}\right)_{2} \mathrm{SO}_{4}$ and the lipoproteins were removed by centrifugation as described by Harboe and Inguild. ${ }^{26}$ The effect of whole human serum, serum heated to $56^{\circ} \mathrm{C}$ for 30 minutes and the immunoglobulin fraction of human serum on adherence of $H$ pylori to Kato III cells was tested by incubating the bacteria with the serum or immunoglobulins for 60 minutes at $37^{\circ} \mathrm{C}$ before use in the adherence assay.

IgA

Purified human sIgA and serum IgA were purchased from Cappel Laboratories (Durham, NC, USA). The effect of IgA on adherence of $H$ pylori to Kato III cells was tested by incubating the bacteria with the immunoglobulins for 60 minutes at $37^{\circ} \mathrm{C}$ before use in the adherence assay.

\section{HUMAN MILK}

Human milk was obtained from women in The Gambia known to be infected with $H$ pylori. Human milk was also obtained from a healthy volunteer in Ireland who was not colonised with $H$ pylori as judged by the ${ }^{13} \mathrm{C}$ urea breath test. The presence of specific anti- $H$ pylori IgA in each of the milk samples was assessed by western immunoblotting. Whole cell lysates of $H$ pylori strain PU3 were run on SDS polyacrylamide gels according to the method of Laemmli et $a .^{27}$ Proteins were transferred to nitrocellulose using a BioRad semi-dry transfer blotter. The nitrocellulose was cut into strips and each strip was blocked with $5 \%$ (wt/vol) Marvel $^{\mathrm{TM}}$ (Chivers, Dublin, Ireland) in Tris buffered saline (TBS) ( $\mathrm{pH} 7 \cdot 4)$ containing $0.05 \%$ (vol $/ \mathrm{vol})$ Tween 20 , incubated in human milk diluted in TBS containing $1 \%$ (wt/ vol) Marvel and $0.05 \%$ ( $\mathrm{vol} / \mathrm{vol}$ ) Tween 20, washed and subsequently incubated in a 1 in 1000 dilution of rabbit antihuman IgA conjugated to peroxidase (Dako, High Wycombe, UK). Blots were developed using the ECL system (Amersham, Buckinghamshire, UK) according to the manufacturer's instructions. The effect of each separate milk sample on adherence of $H$ pylori to Kato III cells was tested by incubating the bacteria with the milk for 60 minutes at $37^{\circ} \mathrm{C}$ before use in the adherence assay.

FRACTIONATION OF HUMAN MILK

The milk was thawed and fat removed by centrifugation at $12000 \mathrm{~g}$ for 15 minutes at $4^{\circ} \mathrm{C}$. Casein was precipitated from the aqueous phase of the sample by adjusting the $\mathrm{pH}$ of the milk to 4.6 with $1 \mathrm{~N} \mathrm{HCl}$. The milk was left at $4^{\circ} \mathrm{C}$ overnight. Precipitated casein was removed by centrifugation for 20 minutes at $10000 \mathrm{~g}$ at $4^{\circ} \mathrm{C}$. The supernatant was dialysed for 24 hours against $0.01 \mathrm{M}$ sodium phosphate (pH 7.5) containing $0.1 \mathrm{M} \mathrm{NaCl}$ and then fractionated by chromatography on DEAE cellulose which was equilibrated in the same buffer. The column was eluted with $0.01 \mathrm{M}$ 
sodium phosphate containing $0.25 \mathrm{M} \mathrm{NaCl}$ at $4^{\circ} \mathrm{C}$. Fractions of $3 \mathrm{ml}$ were collected and the absorbance at $280 \mathrm{~nm}$ monitored. These were analysed on SDS polyacrylamide gels. Fractions containing IgA were detected by western immunoblotting. The nitrocellulose filter was incubated with a 1 in 400 dilution of goat antihuman IgA conjugated to biotin (Sigma, Poole, Dorset, UK). Antigen-antibody complexes were detected using an avidinperoxidase conjugate (Sigma). Blots were developed using 4-chloro-1-naphthol (Sigma) as the substrate. The effect of fractions of human milk on adherence of $H$ pylori to Kato III cells was tested by incubating the bacteria with the fractions for 60 minutes at $37^{\circ} \mathrm{C}$ before use in the adherence assay.

\section{ADHERENCE ASSAY}

The adherence assay used in these experiments was as described previously. ${ }^{28}$ Bacteria and cells were used at a ratio of 200:1. Cells (100 $\mu \mathrm{l})$ were pelleted in a round bottomed tube by centrifugation at $200 \mathrm{~g}$ for five minutes. $H$ pylori suspended in PBS (100 $\mu$; Dulbecco's formula $\mathrm{A}, \mathrm{pH} \mathrm{7.3)}$ was mixed with the pellet of cells and the tube was incubated at $37^{\circ} \mathrm{C}$ for 30 minutes. For inhibition assays, bacteria were suspended in serum, human milk or IgA as described earlier. Non-adherent bacteria were removed by centrifugation through a $15 \%$ ( $\mathrm{vol} / \mathrm{vol}$ ) sucrose solution. Cells were washed once in PBS and subsequently stained with a 1 in 200 dilution of a whole cell $H$ pylori antibody for 30 minutes. The cells were washed twice in PBS and incubated for a further 30 minutes in $100 \mu$ l of a 1 in 80 dilution of fluorescein isothiocyanate (FITC) conjugated goat antirabbit IgG (Sigma). Cells were subsequently washed twice in PBS and resuspended in $100 \mu \mathrm{l}$ of $2 \%$ (vol/vol) formaldehyde. Adherence was assessed by flow cytometry.

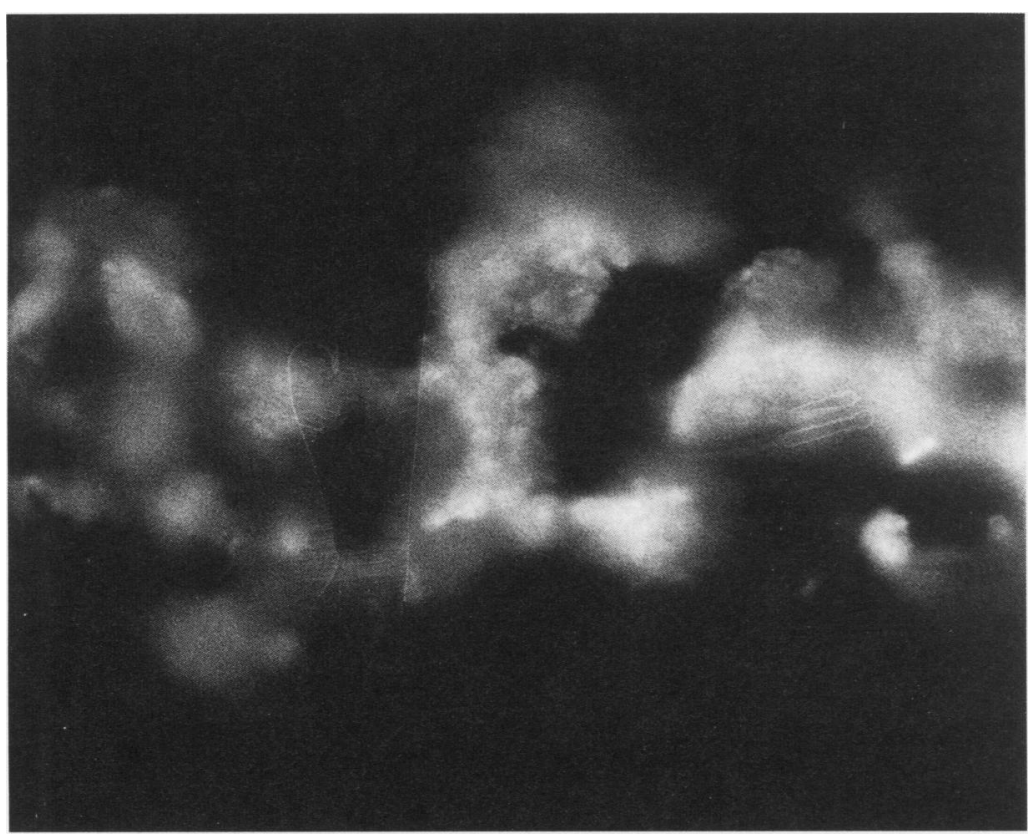

Figure 1: Fluorescence photomicrograph of $\mathrm{H}$ pylori strain PU3 adhering to Kato III cells.
FLOW CYTOMETRY

Adherence of $H$ pylori to epithelial cells was measured using a FACScan flow cytometer (Becton Dickinson, CA, USA). By using a dot plot display of forward and right angle scatter, the machine was gated to include single cells and to exclude most cell debris, clumps of cells and non-adherent bacteria. In total, 10000 gated events were collected and the data were analysed by using the Lysis software program from Becton Dickinson. This program produces histograms of each cell sample and calculates mean channel fluorescence of the cell population, which relates directly to the surface density of fluorescently labelled $H$ pylori adhering to the cell. Results are expressed as the per cent fluorescent cells (that is, the per cent positive events or the percentage of cells with bacteria attached) calculated from fluorescence frequency distribution histograms (the relative number of cells versus the relative fluorescence intensity). The threshold for positivity was set for each experiment by flow cytometric analysis of cells without adherent bacteria which had been stained with anti- $H$ pylori whole cell antibody and the FITC labelled second antibody.

STATISTICAL ANALYSIS

Results are expressed as mean (SD) or mean (SEM) result of at least three experiments. Results were analysed by using the $t$ test.

\section{Results}

EFFECT OF HUMAN SERUM ON ADHERENCE OF H PYLORI TO KATO III CELLS

All the serum from individuals infected with $H$ pylori agglutinated $H$ pylori. No serum from individuals not infected with $H$ pylori agglutinated $H$ pylori. It has been shown that in human serum, the alternative pathway of complement activation, which is independent of antibody, can be bactericidal for $\mathrm{H}$ pylori ${ }^{29}$ We therefore heat treated human serum $\left(56^{\circ} \mathrm{C}\right.$ for 30 minutes) to inactivate complement before use in the adherence assay. The adherence of bacteria to Kato III cells was confirmed by fluorescence microscopy (Fig 1). Serum from both $H$ pylori infected and from non-infected individuals notably decreased the adherence of $H$ pylori to Kato III cells (Fig 2A). However, as expected, this decrease in adherence was the result of lack of viability of the organism after exposure to whole human serum (Fig 2B). Heat treated serum from both $H$ pylori infected and non-infected individuals had no inhibitory effect on $H$ pylori adherence (Fig 2A). Likewise, the $\left(\mathrm{NH}_{4}\right)_{2} \mathrm{SO}_{4}$ precipitates of the serum samples, which are fractions of serum containing immunoglobulin, had no effect on adherence (Fig 2B).

EFFECT OF HUMAN MILK ON ADHERENCE OF H PYLORI TO KATO III CELLS

We tested four different human milk samples collected from women in The Gambia known to be infected with $H$ pylori and one from a 

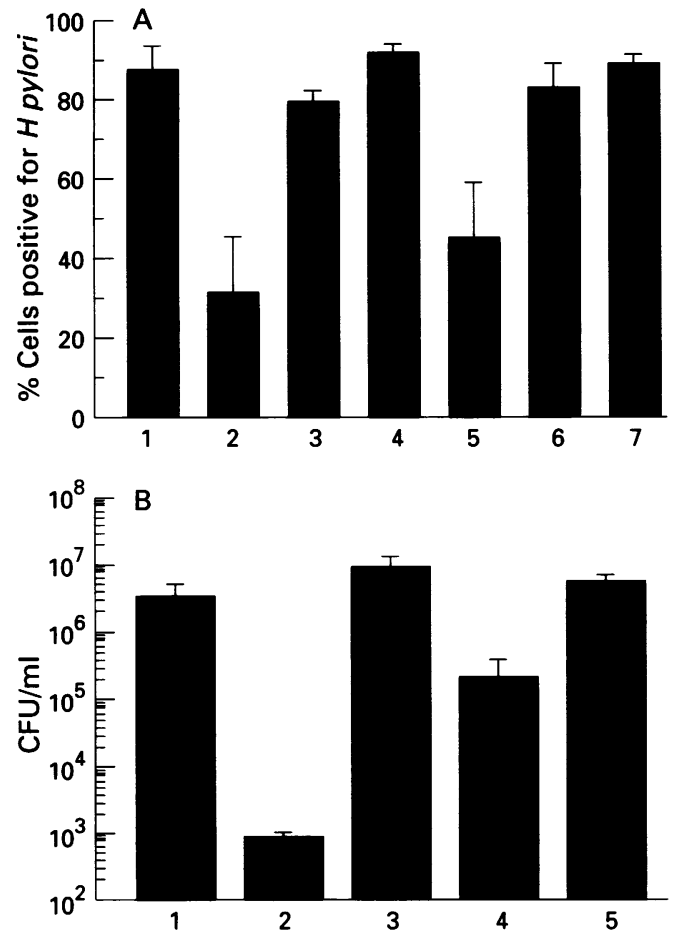

Figure 2: The effect of human serum on adherence of $\mathrm{H}$ pylori to Kato III cells. (A) Bacteria were incubated under microaerophilic conditions with (1) PBS, (2) whole human serum, (3) heat treated serum, and (4) $\left(\mathrm{NH}_{4}\right)_{2} \mathrm{SO}_{4}$ precipitate of serum from a $\mathrm{H}$ pylori infected person, and (5) whole human serum, (6) heat treated serum, and (7) $\left(\mathrm{NH}_{4}\right)_{2} \mathrm{SO}_{4}$ precipitate of serum from a person not infected with $\mathrm{H}$ pylori. Serum was used at a final concentration of $25 \%$ (volvol) and $\left(\mathrm{NH}_{4}\right)_{2} \mathrm{SO}_{4}$ precipitate at a final concentration of $50 \%$ (vol/vol). Adherence of the organism to the cells was assessed by flow cytometry as described in Methods. (B) Bacteria were incubated under microaerophilic conditions with (1) PBS, (2) whole human serum, (3) heat treated human serum from a person infected with $\mathrm{H}$ pylori, (4) whole human serum, and (5) heat treated human serum from a person not infected with $\mathrm{H}$ pylori. Serum was used at a final concentration of $25 \%$ (vol/vol). At the end of the incubation period, CFU/ml present in each bacterial suspension was measured. Results are means (SD) for three experiments.

woman in Ireland who was negative for $\mathrm{H}$ pylori as judged by the ${ }^{13} \mathrm{C}$ urea breath test. The milk from the women infected with $H$ pylori contained IgA which reacted with multiple $H$ pylori proteins as determined by western immunoblotting. The milk from the woman not infected with $H$ pylori did not react with any $H$ pylori proteins (Fig 3). All of these milk samples inhibited adherence of the organism to Kato III cells (Fig 4). Marvel, a low fat powdered milk, had no effect on adherence. The difference in adherence of $H$ pylori cells exposed to $5 \%$ human milk was statistically significant compared with the PBS control $(\mathrm{p}=0.003)$ (Fig 5A). Incubation of $H$ pylori with $5 \%, 10 \%$ and $50 \%$ human milk had a bactericidal effect on the organism which was reduced by heating the milk (Fig $5 \mathrm{~B}$ ). The difference in adherence of bacteria exposed to $5 \%$ heat treated human milk was not significantly different from the PBS control $(p=0.077)$, suggesting that some of the inhibitory activity is a result of the bactericidal effect. However, there was no significant difference in the bactericidal effect of $5 \%, 10 \%$

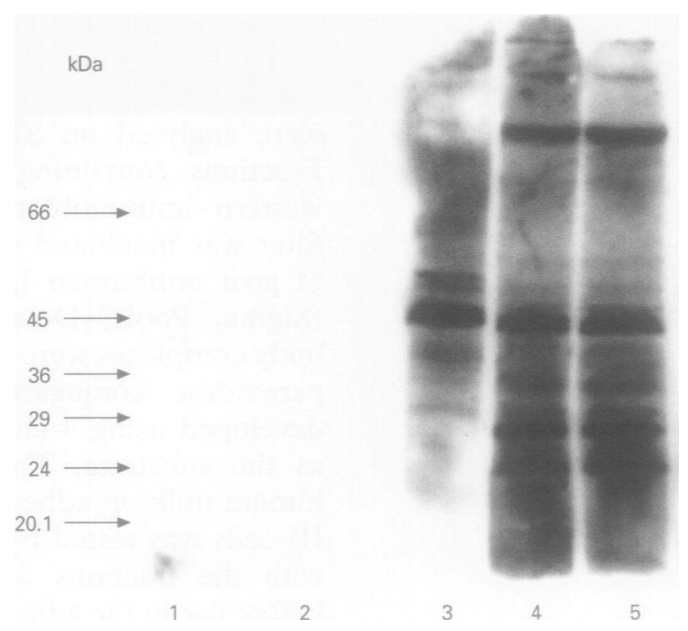

Figure 3: Western blot of IgA antibodies to $\mathrm{H}$ pylori in human milk. Lane 1 was probed with $\operatorname{Ig} A$ (Cappel Laboratories) (diluted 1 in 100). Lane 2 was probed with human milk (diluted 1 in 100) from a woman not infected with $\mathrm{H}$ pylori. Lanes 3 and 4 were probed with human milk (diluted 1 in 400) from women infected with $\mathrm{H}$ pylori. Lane 5 was probed with IgA (diluted 1 in 100) isolated from milk from a woman infected with $\mathrm{H}$ pylori. Left hand figures refer to molecular weight standards in kilodaltons.

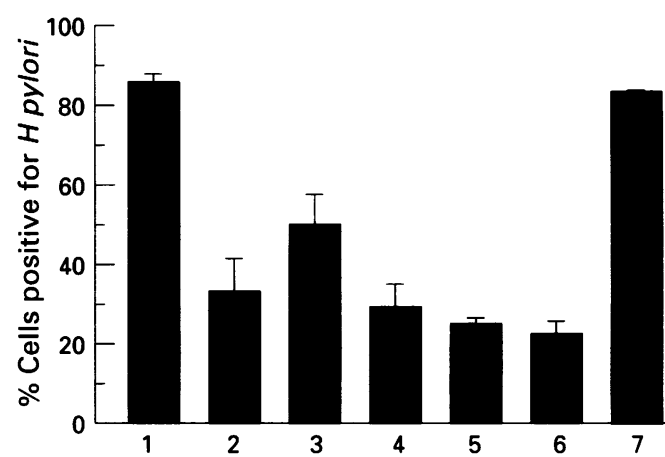

Figure 4: The effect of human milk on adherence of $\mathrm{H}$ pylori to Kato III cells. Bacteria were incubated under microaerophilic conditions with (1) PBS, (2-5) human milk from women infected with $\mathrm{H}$ pylori, (6) human milk from a woman not infected with $\mathrm{H}$ pylori, and (7) low fat powdered milk (Marvel) at $37^{\circ} \mathrm{C}$ for 60 minutes before incubation with Kato III cells. Adherence was assessed by flow cytometry as described in Methods. Milk was

incubated with the bacteria at a final concentration of $50 \%$ (volvol). Results are means (SEM) for three experiments.

and $50 \%$ human milk $(p<0 \cdot 01)$. Clearly, as we increased the concentration of human milk, the inhibitory effect on adherence also increased (Fig 5A). This indicates that other factors in the milk besides the bactericidal activity have a role in inhibiting adherence. The effect of Marvel, assessed for the purpose of comparison, had no effect on the viability of the organism.

FRACTIONATION OF HUMAN MILK

Two human milk samples, one from a woman infected with $H$ pylori and milk from the woman not infected with $H$ pylori were fractionated by chromatography on DEAE cellulose. We identified the fractions which 

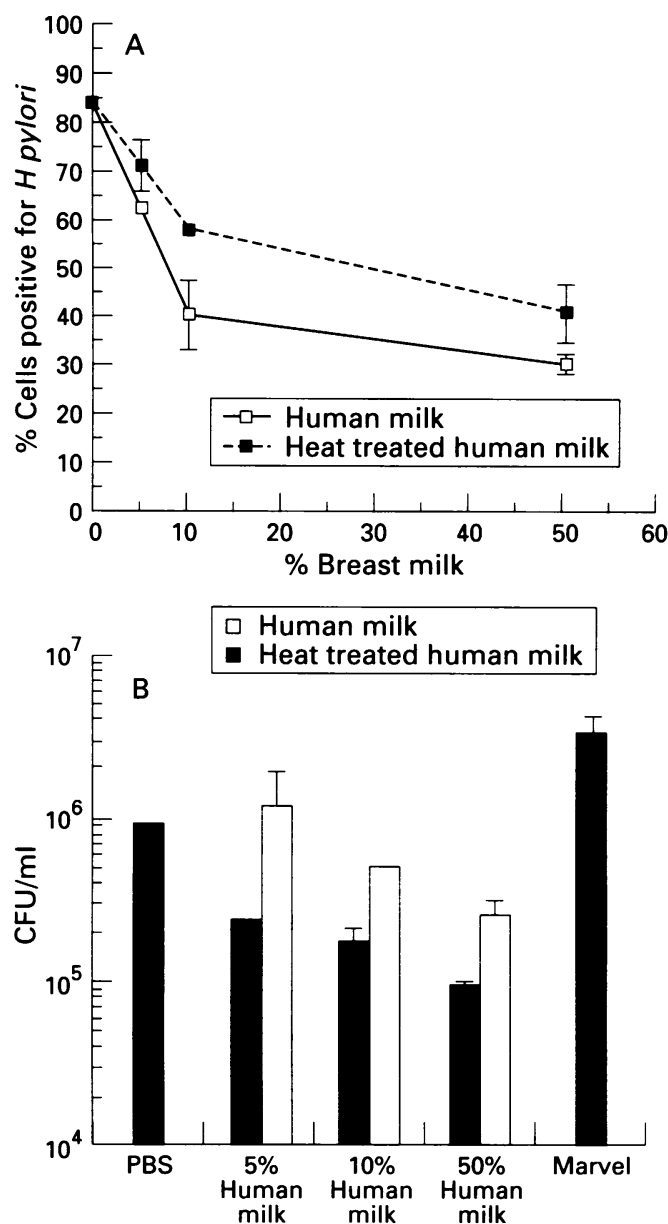

Figure 5: (A) Effect of different concentrations of human milk on adherence of $\mathrm{H}$ pylori to Kato III cells. Bacteria were incubated with different amounts of human milk under microaerophilic conditions before incubation with the cells. The effect of heat treating the human milk $\left(56^{\circ} \mathrm{C}\right.$ for 30 minutes) before incubation with the bacteria was also assessed. (B) Effect of different concentrations of human milk on the viability of $\mathrm{H}$ pylori. The effect of milk which had been heated to $56^{\circ} \mathrm{C}$ for 30 minutes was also assessed. Bacteria were incubated with different concentrations of human milk for 60 minutes at $37^{\circ} \mathrm{C}$ under microaerophilic conditions, after which time CFU/ml present in the solution was measured. Results are means (SD) for three experiments.

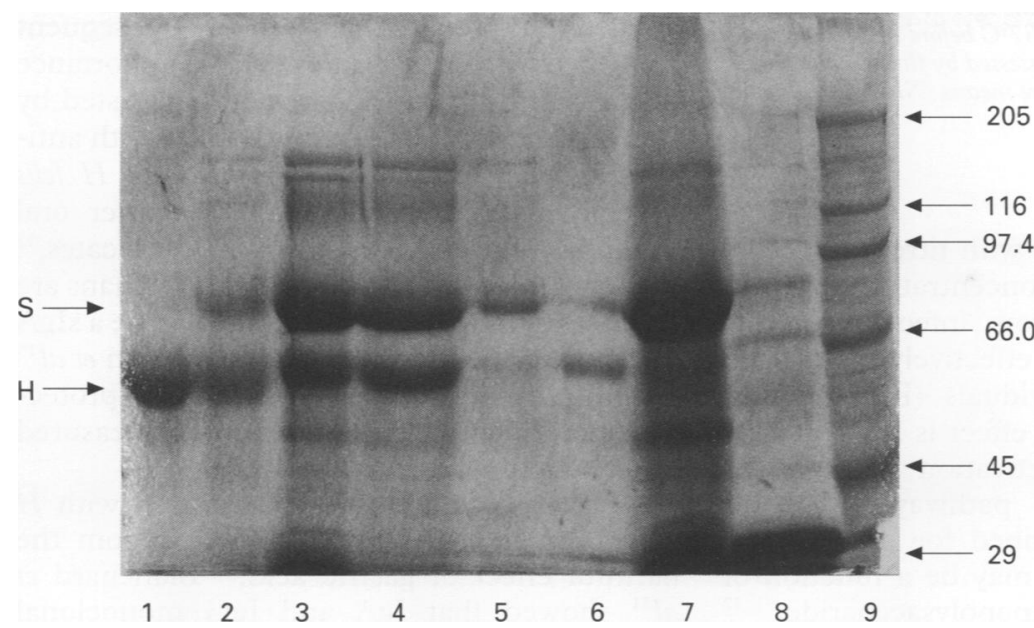

Figure 6: Fractionation of human milk. Different fractions of human milk were analysed by SDS PAGE. The gel contained $12 \%$ acrylamide and was stained with Coomassie Blue.

Lane 1, serum IgA (Cappel Laboratories); lane 2, sIgA (Cappel Laboratories); lane 3, fat free human milk; lane 4, fat free human milk with casein precipitated out; lane 5, fraction eluted from $D E A E$ cellulose column (fraction $A$ ); lane 6, fraction eluted from $D E A E$ cellulose column (fraction B); lane 7, precipitate of human milk containing casein; lane 8 , low fat powdered milk (Marvel); lane 9, molecular weight markers (Sigma). contained IgA by western immunoblotting. These fractions contained either heavy chain IgA or the secretory component of $\operatorname{IgA}$ as the major band when analysed by SDS PAGE (Fig 6). Western immunoblotting confirmed that IgA isolated from the woman infected with $H$ pylori reacted with $H$ pylori antigens (Fig 3).

EFFECT OF HUMAN MILK COMPONENTS ON ADHERENCE OF H PYLORI TO KATO III CELLS The effect of different components of human milk on adherence of $H$ pylori to Kato III cells was tested. The components tested were (1) a human milk sample from which the casein had been precipitated out, (2) a precipitate of human milk containing casein, (3) a fraction eluted from the DEAE cellulose column which contained heavy chain IgA, and (4) a fraction eluted from the DEAE cellulose column which contained the secretory component of $\operatorname{IgA}$ as analysed by SDS PAGE. None of the fractions tested had the inhibitory capacity of fat free human milk. In every case components isolated from immune human milk had slightly more inhibitory activity than the equivalent fraction isolated from the milk of the woman not infected with $H$ pylori, but this result was not statistically significant ( $>>0.05)$ (Fig 7).

EFFECT OF IgA ON ADHERENCE OF H PYLORI TO KATO III CELLS

We tested the effect of commercially obtained serum IgA and $\operatorname{SIgA}$ at concentrations ranging from $15 \mu \mathrm{g} / \mathrm{ml}$ to $750 \mu \mathrm{g} / \mathrm{ml}$ on the adherence of $H$ pylori to Kato III cells. Even at a concentration as high as $750 \mu \mathrm{g} / \mathrm{ml}$, serum IgA had no effect on adherence of the organism to Kato III cells. At the same concentration, sIgA had minimal inhibitory effect on adherence (Fig 8).

\section{Discussion}

Despite a strong persistent serological and local immune response to $H$ pylori, the organism is not eradicated from the host. In this study we have shown that the systemic antibody response and the sIgA response do not inhibit the organism from adhering to gastric cells in vitro. This may explain why chronic infection develops in infected subjects despite a vigorous immune response.

Human serum from both infected and noninfected subjects exerted a bactericidal effect on $H$ pylori (Fig 2). Heat inactivation abolished the killing effect of the serum samples on the organism, strongly suggesting that it was complement mediated. This is in agreement with the findings of Rautelin et al. ${ }^{29}$ More recently, it has been reported that bovine normal serum and serum from immunised cows is highly bactericidal for $H$ pylori. ${ }^{30}$ This bactericidal effect is destroyed by heating to $56^{\circ} \mathrm{C}$ for 30 minutes and restored by the addition of fetal calf serum as a source of complement, indicating that the bactericidal effect is probably dependent on an antibodycomplement system. However, the bactericidal 


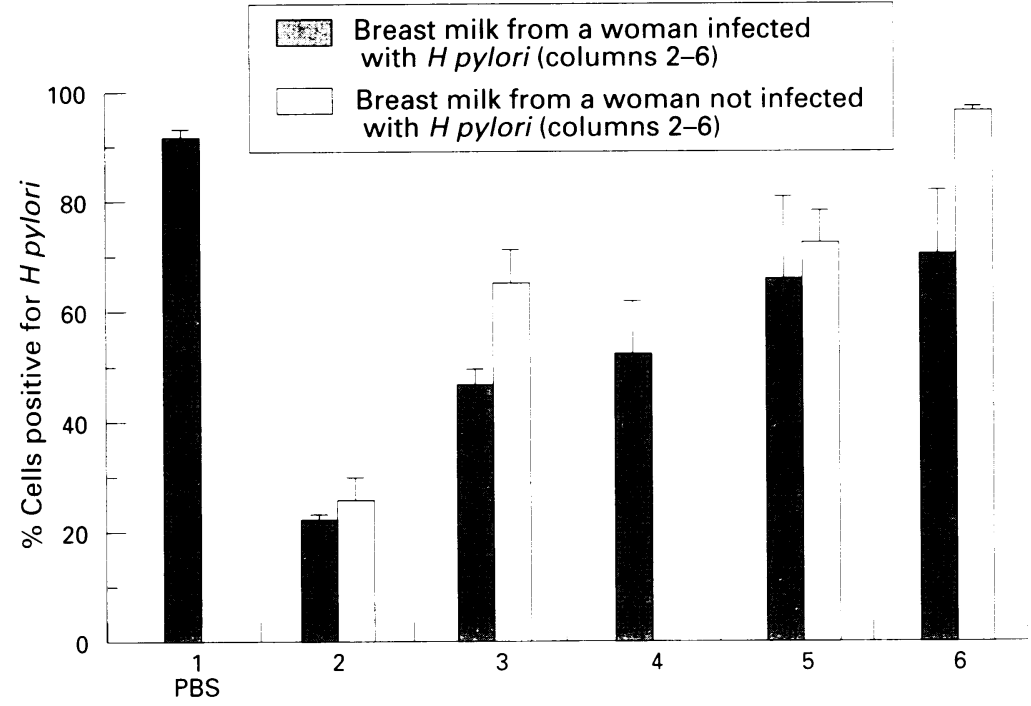

Figure 7: Effect of human milk components on adherence of $\mathrm{H}$ pylori to Kato III cells. $\mathrm{H}$ pylori was incubated under microaerophilic conditions with (1) PBS, (2) fat free human milk (final concentration $50 \% \mathrm{vol} / \mathrm{vol}$ ), (3) human milk with the casein precipitated out (final concentration of $50 \% \mathrm{vol} / \mathrm{vol}$ ), (4) casein containing precipitate at a concentration of $750 \mu \mathrm{g} / \mathrm{ml}$ (this was not tested for the milk from the non-infected woman), (5) fraction $A$ from DEAE cellulose column at a concentration of $750 \mu \mathrm{g} / \mathrm{ml}$, and (6) fraction $B$ from $D E A E$ cellulose column at a concentration of $750 \mu \mathrm{g} / \mathrm{ml}$ for 60 minutes at $37^{\circ} \mathrm{C}$ before incubation with the cells. Adherence was assessed by flow cytometry as described in Methods. Results are means (SEM) for three experiments.

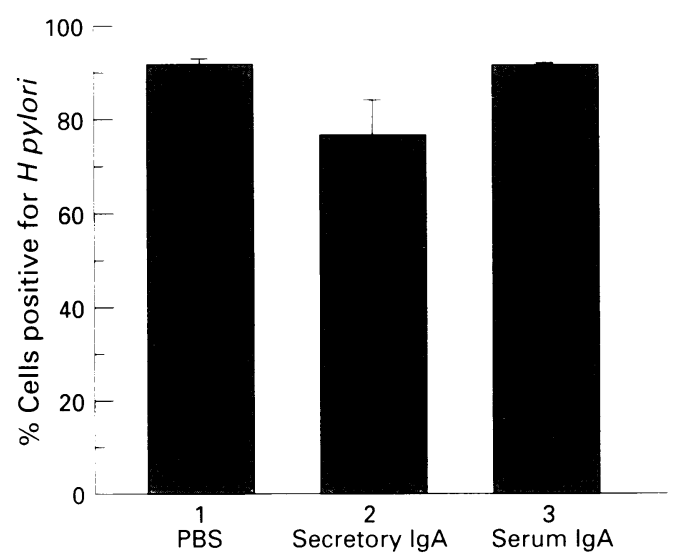

Figure 8: The effect of $\operatorname{Ig} A$ on adherence of $\mathrm{H}$ pylori to Kato III cells. Serum IgA and $\operatorname{Ig} A$ were purchased from Cappel Laboratories. Bacteria were incubated under microaerophilic conditions with the $\operatorname{Ig} A$ at a concentration of $750 \mu \mathrm{g} / \mathrm{ml}$ for 60 minutes at $37^{\circ} \mathrm{C}$ before incubation with Kato III cells. Adherence was assessed by flow cytometry as described in Methods. Results are means (SEM) for three experiments.

activity did not correlate with titres of specific antibody or with IgG concentrations. In our study serum samples from infected subjects killed the organism more effectively than serum from non-infected individuals (Fig 2), indicating that some of this effect is mediated by the classic pathway. Activation of both the alternative and classic pathways of complement has been described for other Gram negative pathogens and may be a function of antibody binding to the lipopolysaccharide. ${ }^{31} 32$ Serum susceptibility of an organism restricts access of that organism to the systemic circulation. Blaser et $a l^{33}$ found that Campylobacter jejuni or $C$ coli isolates from faeces were serum sensitive. In contrast, $C$ fetus strains isolated chiefly from systemic sites in humans were always serum resistant. Despite being a chronic infection, $H$ pylori is not invasive and does not spread to other sites in the immunocompetent host. The stomach seems to be the only site where $H$ pylori infection persists. The bacteria are prevented from invading the gastric mucosa and under normal circumstances minimal symptomatology results, suggesting that host defences, such as complement, are effective in limiting the spread of infection under ordinary circumstances.

The decrease in adherence of $H$ pylori to Kato III cells caused by preincubation of the organism with serum correlated with lack of viability of the organism under these conditions (Fig 2). Heat inactivation of the serum restored viability of the organism and ability to adhere to gastric cells. The $\left(\mathrm{NH}_{4}\right)_{2} \mathrm{SO}_{4}$ precipitates of serum, which contain the immunoglobulins, had no effect on adherence. This was not surprising as it is widely speculated that a local sIgA response is required to confer protection against $H$ pylori in the gastric mucosa.

We therefore decided to study the effect of secretory IgA on $H$ pylori adherence. Breast milk from infected women and from a noninfected woman notably decreased the adherence of $H$ pylori to Kato III cells (Fig 4). This could have been partly because of loss of viability of the organism that occurred in human milk. However, there was no significant difference in the bactericidal effect of $5 \%, 10 \%$ and $50 \%$ human milk $(p<0.01)$, but as we increased the concentration of human milk the inhibitory effect on adherence also increased (Fig 5). This indicates that other factors in the milk besides the bactericidal activity play a part in inhibiting adherence.

Secretory IgA had a minimal inhibitory effect on adherence. To date, vaccination studies for $H$ pylori have mainly relied on the $H$ felis mouse model of infection. Workers have used, in combination with cholera toxin, either a whole $H$ felis lysate ${ }^{17}$ or purified $H$ pylori urease subunits. ${ }^{18-20}$ Immunisation of mice with these antigens protects them from subsequent challenge with $H$ felis. The possible importance of $\operatorname{sIgA}$ at the mucosal surface is suggested by successful passive oral immunisation with anti$H$ felis $\operatorname{IgA}^{22}$ and by the presence of $H$ felis specific gastric and intestinal IgA after oral immunisation of mice with $\mathrm{H}$ felis sonicates. ${ }^{17}$ In contrast to these animal models, humans are persistently colonised by $H$ pylori despite a $\operatorname{sigA}$ response in the gastric mucosa. Michetti et al ${ }^{19}$ did not observe a correlation between protection and specific IgA concentrations measured in blood and intestinal secretions.

Urease is essential for colonisation with $H$ pylor $^{34}$ as it protects the organism from the harmful effect of gastric acid. ${ }^{35}$ Blanchard et $a l^{21}$ showed that IgA and IgG monoclonal antibodies against $H$ felis urease inhibited colonisation of mice by $H$ felis. However, these antibodies did not neutralise urease activity in vitro. The antibodies may inhibit colonisation by agglutinating the bacteria and promoting removal by peristalsis and mucus flow. 
Casein accounts for almost half of the protein content in human milk. Human milk $\kappa$-casein but not $\beta$-casein inhibits $H$ pylori adhesion to fixed sections of human gastric mucosa. ${ }^{36}$ We found that casein had an inhibitory effect on $H$ pylori adherence to Kato III cells, but the fraction of milk with casein removed also had an inhibitory effect (Fig 7). Inhibition of adherence of $H$ pylori to gastric cells by human milk is likely to be because of a number of different factors. Oligosaccharides present in human milk inhibit the attachment in vitro of various bacteria. ${ }^{12} 37$ Fucose has been previously associated with inhibition of the ability of Vibrio cholerae to haemagglutinate human O-group erythrocytes. ${ }^{38} \mathrm{~A}$ recent study has shown that $H$ pylori binds to the Lewis $\mathrm{B}$ blood group antigen, and that antibodies against this antigen and soluble Lewis B glycoprotein inhibit binding of the organism to gastric tissue. ${ }^{39}$ Glycosylation patterns of soluble glycoconjugates, which are natural receptor analogs in secretions such as human milk and saliva, may act as clearance factors and reduce bacterial adherence and colonisation. Mucin, which is another component of human milk, has been shown to inhibit rotavirus replication ${ }^{40}$ and to inhibit adhesion of S-fimbriated Escherichia coli to human buccal epithelial cells. ${ }^{41}$

Human serum is bactericidal for $H$ pylori and probably prevents systemic spread of the organism. Inhibition of adherence of $H$ pylori to gastric cells by human milk seems to be mediated by the non-immunoglobulin fraction of the milk. People infected with $H$ pylori do not seem to raise antibodies in serum or in local secretions which are capable of inhibiting adherence of the organism to gastric cells, which may be one explanation why chronic infection occurs in non-treated subjects. In support of these findings it has been reported recently that prior infection of ferrets with $H$ mustelae did not confer universal protection against subsequent infection. ${ }^{42}$

This work was supported by a grant from The Children's Research Centre, Our Lady's Hospital for Sick Children, Crumlin, Dublin 12, Ireland.

1 Hentschel E, Brandstatter G, Dragosics B, Hirschl A, Nemec $\mathrm{H}$, Schutze $\mathrm{K}$, et al. Effect of ranitidine and amoxicillin plus metronidazole on the eradication of Helicobacter pylori and the recurrence of duodenal ulcer. N Engl F Med 1993; 328: 308-12.

2 Graham DY. Treatment of peptic ulcers caused by Helicobacter pylori. N Engl f Med 1993; 328: 349-50.

3 Drumm B, Sherman P, Cutz E, Karmali M. Association of Campylobacter pylori on the gastric mucosa with antral Campylobacter pylori on the gastric mucosa with antral

4 Goodwin CS, Armstrong JA, Marshall BJ. Campylobacter pyloridis, gastritis and peptic ulceration. $f$ Clin Pathol 1986; 39: 353-65.

5 Marshall BJ, Warren JR. Unidentified curved bacilli in the stomach of patients with gastritis and peptic ulceration. Lancet 1984; i: $1311-5$.

6 Mitchell HM, Li YY, Hu PJ, Liu Q, Chen M, Du GG, et al. Epidemiology of Helicobacter pylori in southern China - Identification of early childhood as a critical period for acquisition. F Infect Dis 1992; 166: 149-53.

7 Wyatt JI, Rathbone BJ, Dixon MF, Heatley RV. Campylobacter pyloridis and acid induced gastric metapasia in the pathogenesis of duodenitis. I Clin Pathol 1987; 40: pathogen

8 Hayani KC, Guerrero ML, Morrow AL, Gomez HF, Winsor DK, Ruiz-Palacios GM, et al. Concentration of milk secretory immunoglobulin A against Shigella virulence plasmid-associated antigens as a predictor of symptom status in Shigella-infected breast-fed infants. $\mathcal{F}$ Pediatr 1992; 121: 852-6.
9 Michetti P, Mahan MJ, Slauch JM, Mekalanos J, Neutra MR. Monoclonal secretory immunoglobulin A protects mice against oral challenge with the invasive protects mice against oral challenge with the invasive pathogen Salm

10 Ruiz-Palacios GM, Calva JJ, Pickering LK, Lopez-Vidal Y, Volkow P, Pezzarossi H, et al. Protection of breast-fed infants against Campylobacter diarrhea by antibodies in human milk. F Pediatr 1990; 116: 707-13.

11 Cleary TG, Winsor DK, Reich D, Ruiz-Palacios G, Calva JJ. Human milk immunoglobulin A antibodies to Shigella virulence determinants. Infect Immun 1989; 57: 11675-9.

12 Cravioto A, Tello A, Villafan H, Ruiz J, del Vedovo S, Neeser JR. Inhibition of localised adhesion of enteropathogenic Escherichia coli to Hep-2 cells by immunoglobulin and oligosaccharide fractions of human munoglobulin and oligosaccharide fractions of human colostrum

13 Williams RC Gibbons RJ. Inhibition of bacterial adherence by secretory immunoglobulin A: a mechanism of antigen disposal. Science 1972; 177: 697-9.

14 Crabtree JE, Taylor JD, Wyatt JI, Heatley RV, Shallcross TM, Tompkins DS, et al. Mucosal IgA recognition of Helicobacter pylori $120 \mathrm{kDa}$ protein, peptic ulceration and gastric pathology. Lancet 1991; 338: 332-5.

15 Rathbone BJ, Wyatt II, Worsley BW, Shires SE, Trejosiewicz LK, Heatley RV, et al. Systemic and local Trejosiewicz $\mathrm{LK}$, Heatley $\mathrm{RV}$, et al. Systemic and local antibody responses to gastric Campylobacter

16 Czinn SJ, Nedrud JG. Oral immunization against Helicobacter pylori. Infect Immun 1991; 59: 2359-63.

17 Lee A, Chen M. Successful immunization against gastric infection with Helicobacter species: use of a cholera toxin B-subunit-whole-cell vaccine. Infect Immun 1994; 62: 3594-7.

18 Pappo J, Thomas WD, Kabok Z, Taylor NS, Murphy JC, Fox JG. Effect of oral immunization with recombinant urease on murine Helicobacter felis gastritis. Infect Immun 1995; 63: 1246-52.

19 Michetti PI, Corthesy-Thaulaz I, Davin C, Haas R, Vaney AC, Heitz M, et al. Immunization of Balb/c mice against Helicobacter felis infection with Helicobacter pylori urease. Gastroenterology 1994; 107: 1002-11.

20 Ferrero RI, Thiberge JM, Huerre M, Labigne A. Recombinant antigens prepared from the urease subunits of Helicobacter spp: evidence of protection in a mouse model of gastric infection. Infect Immun 1994; 62: 4981-9.

21 Blanchard TG, Czinn SJ, Maurer R, Thomas WD, Soman G, Nedrud JG. Urease specific monoclonal antibodies prevent Helicobacter felis infection in mice. Infect Immun 1995; 63: 1349-99.

22 Czinn SJ, Cai A, Nedrud JG. Protection of germ-free mice from infection by Helicobacter felis after active oral or passive IgA immunization. Vaccine 1993; 11: 637-42.

23 Thomas JE, Austin S, Dale A, McClean P, Harding M, Coward WA, et al. Protection by human milk IgA against Helicobacter pylori infection in infancy. Lancet 1993; 342: 121.

24 Drumm B, Sherman P. Long term storage of Campylobacter pylori. f Clin Microbiol 1989; 27: 1655-6.

25 Leinonen M. Serological methods for the study of bacterial surface antigens. In: Korhonrn TK, Dawes EA, Makela PH, eds. FEMS Symposium no. 25. Enterobacterial surface antigens. Methods for molecular characterisation. Amsterdam: Elsevier Science, 1985: 179-206.

26 Harboe N, Ingild A. Immunization, isolation of immunoglobulins, estimation of antibody titres. Scand $\mathcal{F}$ Immunol globulins, estim

27 Laemmli UK. Cleavage of structural proteins during the assembly of the head of bacteriophage T4. Nature 1970; 227: $680-5$.

28 Clyne M, Drumm B. Adherence of Helicobacter pylori to primary human gastrointestinal cells. Infect Immun 1993; 61: 4051-7.

29 Rautelin H, Blomberg B, Fredlund H, Jarnerot G, Danielsson D. Incidence of Helicobacter pylori strains activating neutrophils in patients with peptic ulcer disease. Gut 1993; 34: 599-603.

30 Korhonen H, Syvaoja EL, Ahola-Luttila H, Sivela S, Kopola S, Husu J, et al. Bactericidal effect of bovine normal and immune serum, colostrum and milk against nelicobacter pylori. $f$ Appl Bacteriol 1995; 78: 655-62.

31 Tvenstrup-Jensen E, Kharazmi A, Garred P, Gitte G, Fomsgaard A, Mollnes TE, et al. Complement activation by Pseudomonas aeruginosa biofilms. Microbial Pathog 1993; 15: 377-88

32 Horiba N, Maekawa Y, Yamauchi Y, Ito M, Matsumoto T, Nakamura H. Complement activation by lipopolysaccharides purified from Gram-negative bacteria isolated from infected root canals. Oral Surg Oral Med Oral Pathol 1992; 74: 648-51.

33 Blaser MJ, Smith PF Kohler PF. Susceptibility of Campylobacter isolates to the bactericidal activity of human serum. F Infect Dis 1985; 151: 227-35.

34 Eaton KA, Brooks CL, Morgan DR, Krakowka S. Essential role of urease in pathogenesis of gastritis induced by Helicobacter pylori in gnotobiotic piglets. Infect Immun 1991; 59: 2470-5.

35 Clyne M, Labigne A, Drumm B. Helicobacter pylori requires an acidic environment to survive in the presence requires an acidic environment to survive in

36 Stromgvist M, Falk P, Bergstrom S, Hansson L, Lonnerdal $\mathrm{B}$, Normark S, et al. Human milk $\mathrm{k}$-casein and inhibition 
of Helicobacter pylori adhesion to human gastric mucosa. 7 Pediatr Gastroenterol 1995; 21: 288-96.

Therora Eden C. Inhibition of attachment of Streptococcus pneumoniae and Haemophilus influenzae by human milk and receptor oligosaccharides. F Infect Dis 1986; 153: $232-7$

38 Jones GW, Freter R. Adhesive properties of Vibrio cholerae: nature of the interaction with isolated rabbit brush border membranes and human erythrocytes. Infect Immun 1975; 14: $240-5$.

39 Boren T, Falk P, Roth KA, Larson G, Normark S. Attachment of Helicobacter pylori to human gastric epithelium is mediated by blood group antigens. Science 1993; 262: 1892-5
40 Yolken RH, Peterson JA, Vanderfecht SL, Fouts ET, Midthun K, Newburg DS. Human milk mucin inhibits rotavirus replication and prevents experimental gastroenteritis. F Clin Invest 1992; 90: 1984-91.

41 Schroten $\mathrm{H}$ Hanisch FG Plogmann $\mathrm{R}$ Hacker J Uhlenbruck G, Nobis-Bosch R, et al. Inhibition of adhesion of S-fimbriated Escherichia coli to buccal epithelial cells by human milk fat globule membrane components: a novel aspect of the protective function of mucins in the non-immunoglobulin fraction. Infect Immun 1992; 60: 2893-9.

42 Batchelder M, Fox JG, Hayward A, Yan L, Shames B, Murphy JC, et al. Natural and experimental Helicobacte mustelae reinfection following successful antimicrobial eradication in ferrets. Helicobacter 1996; 1: 34-42. 